\title{
Effect of Oil Paint Fumes Inhalation on the Level of Serum Thyroid Hormones and Thyroid Stimulating Hormone in Rats
}

\author{
Siavashi M.* MSc, Ahmadi R.1 PhD \\ *Biology Department, Basic Sciences Faculty, Islamic Azad University, Hamedan Branch, Hamedan, Iran \\ 1Biology Department, Basic Sciences Faculty, Islamic Azad University, Hamedan Branch, Hamedan, Iran
}

\begin{abstract}
Aims: The exposure to chemical materials and colors affects thyroid gland functions. The aim of this study was to investigate the effects of fume inhalation of oil-based paints on the serum level of thyroid hormones in female and male rats.

Materials \& Methods: In the experimental study, 15 male and 15 female Wistar rats were studied. The rats were divided into six 5-rat groups including a control group and groups with either 1- or 8-hour a day exposure to the paint fumes by gender division. The serum levels of $\mathrm{T}_{3}, \mathrm{~T}_{4}$, and TSH thyroid hormones were measured after 10 weeks. Data was analyzed by SPSS 20 software using two-way ANOVA and Tukey's post-hoc.

Findings: Mean values of $\mathrm{T}_{3}$ and $\mathrm{T}_{4}$ hormones were significantly reduced in both 1- and 8-hour male and female groups than control group $(\mathrm{p}<0.001)$. In addition, the more the inhalation time, the more the reduction was. Any reduction in $\mathrm{T}_{3}$ in females in 1-hour $(\mathrm{p}<0.001)$ and 8 -hour $(\mathrm{p}<0.05)$ groups was significantly more than the males. Nevertheless, a significant reduction in $\mathrm{T}_{4}$ was only in 1 -hour group $(\mathrm{p}<0.001)$. Mean TSH hormone was significantly increased due to the inhalation of paint fume than control group $(p<0.001)$. In addition, such an increase was significant in the female rats in 8-hour group than the male group $(\mathrm{p}<0.01)$.

Conclusion: The inhalation of oil-based paint fume leads to a reduction in the serum levels of $\mathrm{T}_{3}$ and $\mathrm{T}_{4}$ thyroid hormones, while increases TSH serum level. Such an effect is stronger in the females.
\end{abstract}

\section{Keywords}

Oil-Paint Fume [Not in MeSH];

Thyroid Hormones [http://www.ncbi.nlm.nih.gov/mesh/68013963];

Thyroid-Stimulating Hormone [http://www.ncbi.nlm.nih.gov/mesh/68013972];

Rats [http://www.ncbi.nlm.nih.gov/mesh/68051381]

\footnotetext{
* Corresponding Author

Tel: +988134494000

Fax: +988134494026

Address: Biology Department, Faculty of Basic Sciences, Islamic Azad University of Hamedan, Professor Mussivand

Bulverde, Madani Town, Hamedan, Iran

msiavashi80@yahoo.com

Received: July 23, $2015 \quad$ Accepted: May 10, $2016 \quad$ ePublished: June 30, 2016
} 
توسط غده تيروئيد ساخته و ترشح مىشوند. هورمونهاى تيروئيدى

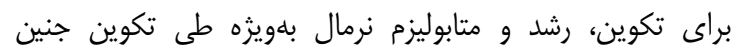

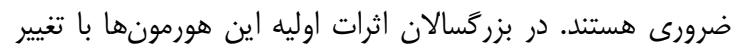

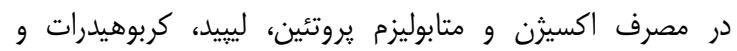

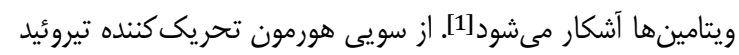

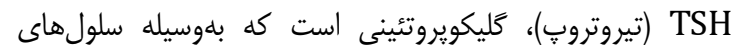

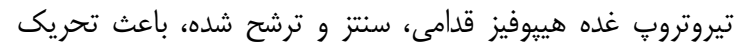

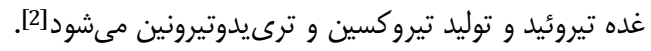

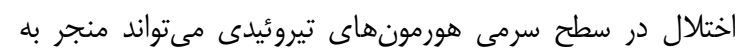

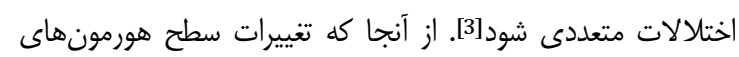

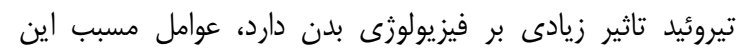

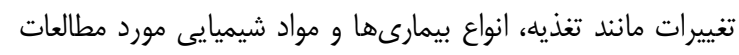

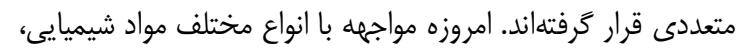

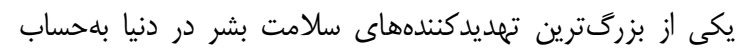

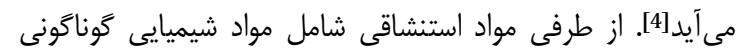

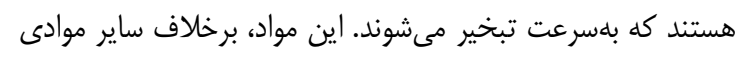

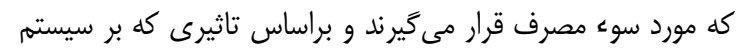

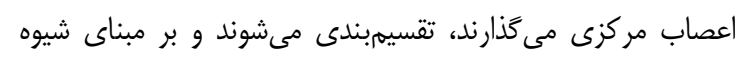

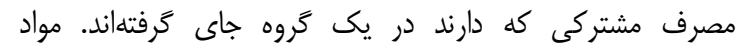

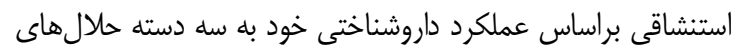

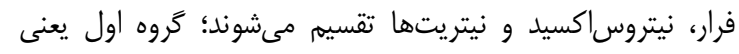

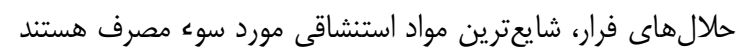

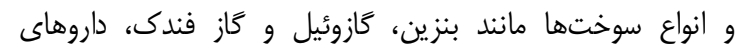

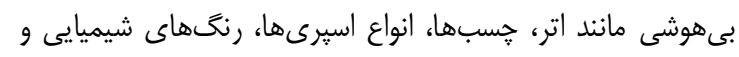

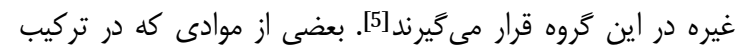

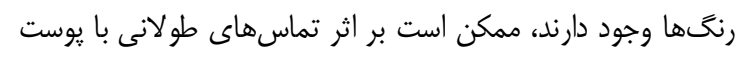

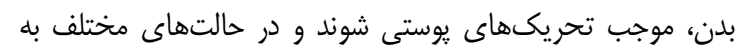

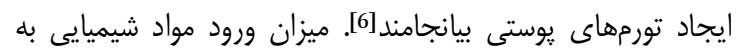

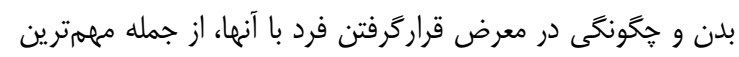

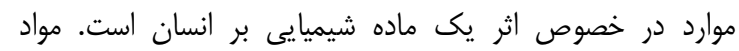

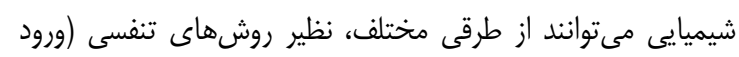

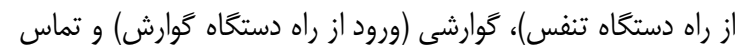

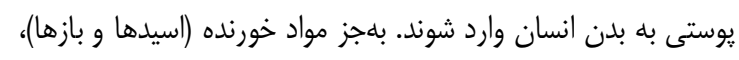

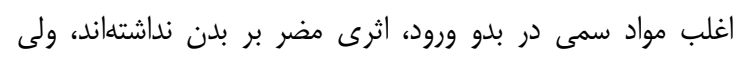

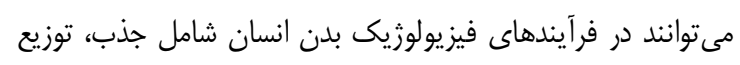

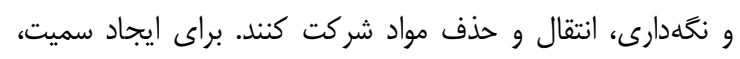

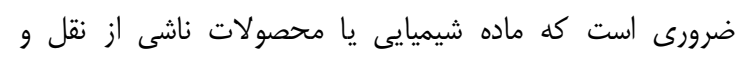

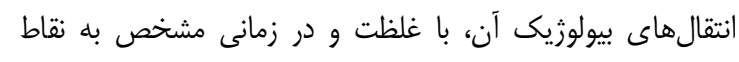

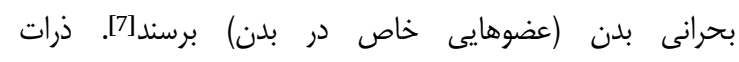

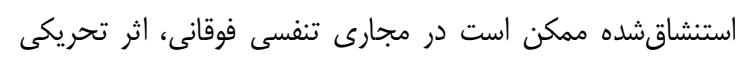

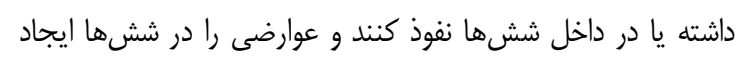
كنند كه به اختلالهايى در اعمال تنفسى منجر شوند.
اثرات استنشاق بخارات رنتى روغنى بر سطح

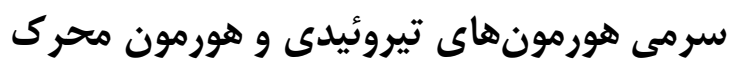
تيروئيد در موشىهاى صحرايى

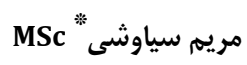

كَروه زيستشناسى، دانشكده علوم بايه، واحد همدان، دانشكاه آزاد اسلامى، همدان، ايران

PhD رحيم احمدى ايران

كروه زيستشناسى، دانشكده علوم بايه، واحد همدان، دانشكاه آزاد اسلامى، همدان، ايران

جكيده

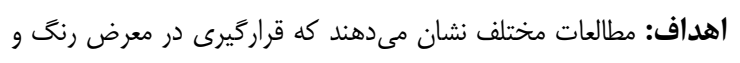

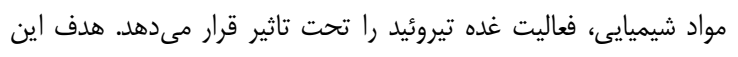

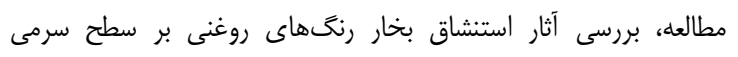

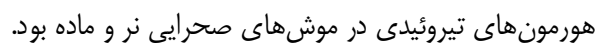

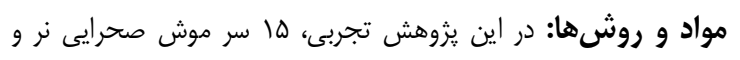

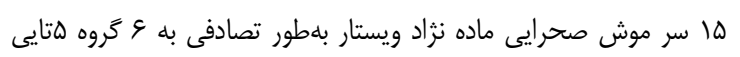

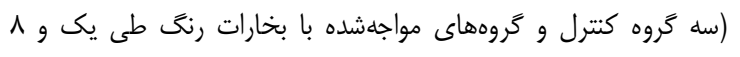

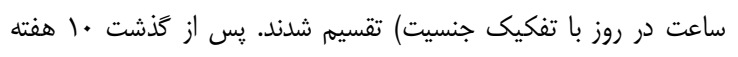
سطح سرمى هورمونهاى تيروئيدى

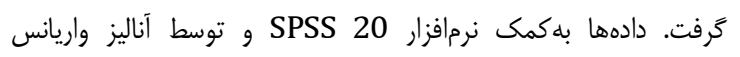
دوطرفه و آزمون توكى تحليل شدند.

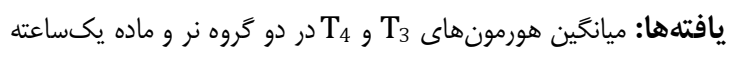

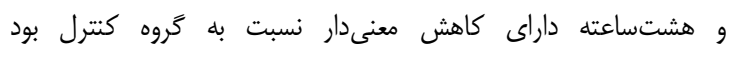

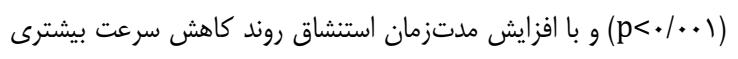

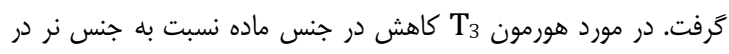

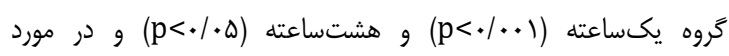

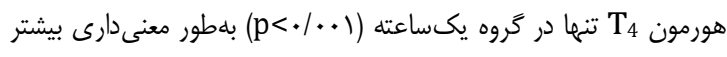

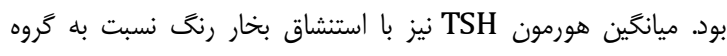

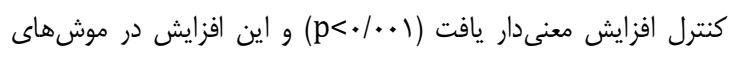

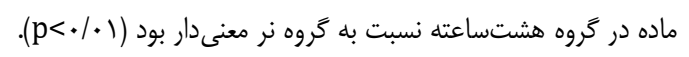

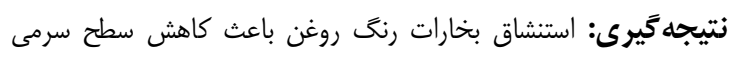

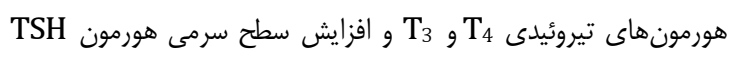
مىشود كه اين تاثير در جنس ماده بيشتر است.

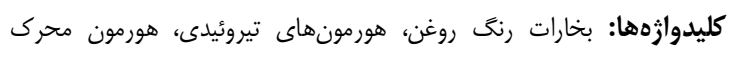
تيروئيد، موش صحرايى نارات

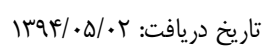

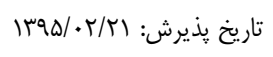
"نويسنده مسئول: msiavashi80@yahoo.com

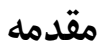

هورمونهاى تيروئيدى شامل تيروكسين (T) مونه ) و ترىيدوتيرونين

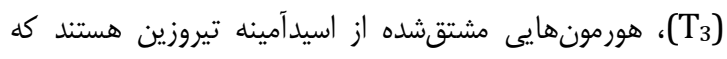

دوره זr، شماره r. تابستان هوسا فصل فامه افق دانش 


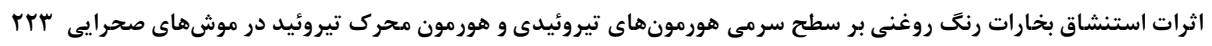

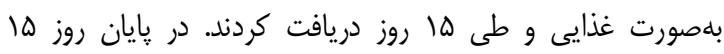

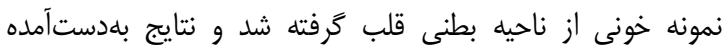

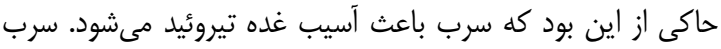

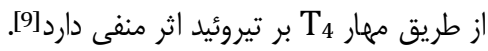

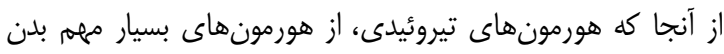
هستند كه عملكرد سيستمهاى مختلف بدن را تحت تاثير خود قرار

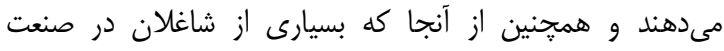
رنگسازى يا شاغلان در حرفه رنغَآميزى ساختمانها و تاسيسات،

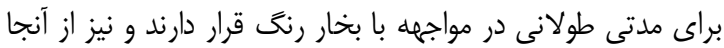

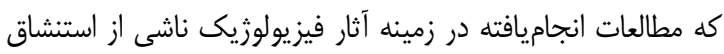
مواد شيميايى از جمله رنگهاى روغنى در مواردى قابل توجه،

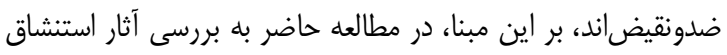

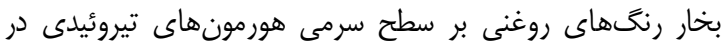

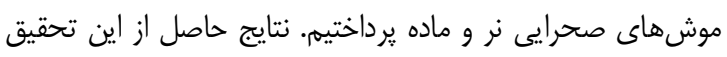
در حوزه رعايت اصول بهراشتى و ييشخيرى از مواجها با بخار

رنتهاى روغنى بلمنظور حفظ سلامت بدن، موثر خواهند بود.

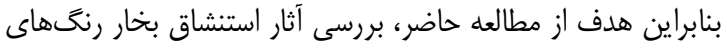
روغنى بر سطح سرمى هورمونهاى تيروئيدى در موشهاى صحرايى نر و ماده بود.

\section{مواد و روشها}

در اين يزوهش تجربى - آزمايشگاهى كه در سال سوسا در دانشگاه أزاد اسلامى واحد همدان انجام شد، ها سر موش صحرايى نر و ها ها

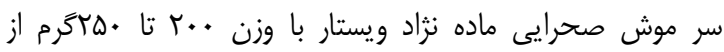

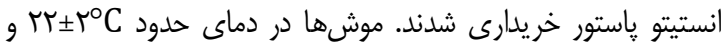

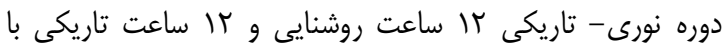

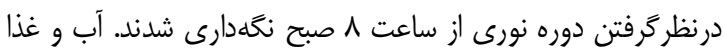

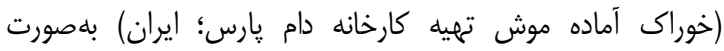

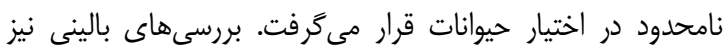

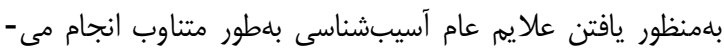

حيوانات بهصورت تصادفى به و گروه هتايى تقسيه شدند؛ دو گروه كنترل نر و ماده كه طى دوره آزمايش هيج مادهاى استنشاق نكردند

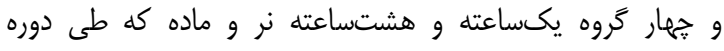

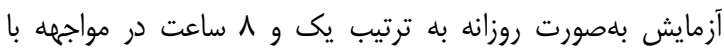

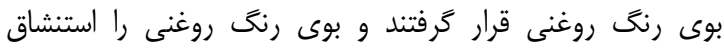
كردند. براى نخمدارى موشها قفسهاى مخصوصى از جنس شيشه بهشكل آكواريوم تعبيه شد و روى قفسها با تورى فلزى و ويكى بشقاب مشبك يوشانده شد. سطح داخلى قفسها با يوشال يوشانده شد، زيرا بهدليل آلودهبودن خاكاره با موجودات ريز ميكروسكويى دئي

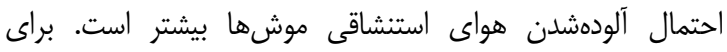

از جمله ذرات معلق در هوا، عنصر سرب است (كه يكى از مواد

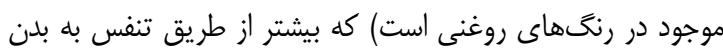

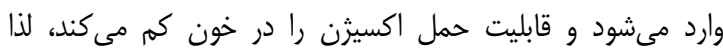
اكسيثن كافى به مغز نمىرسد. اين نارسايى در كودكان مىتواند به

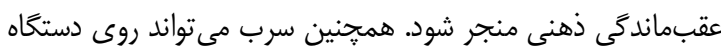

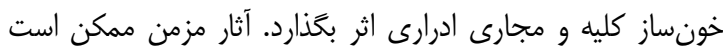
مواردى نظير سردرد، ضعف، سستى، يبوست، خط آبى يا بورتون در

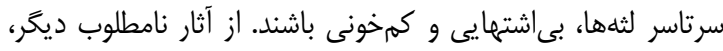
كاهش ميدان ديد است كه بر اثر اين كاهش، حمل بهرونقل باست

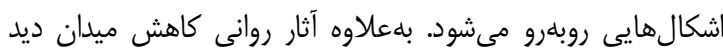

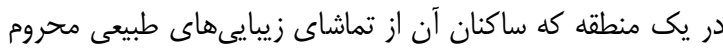

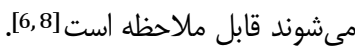
غلظت بخار موجود در هواى محيط به ميل ميزان فراربودن حلال

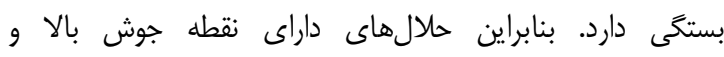
نرمكنندهها، كمخطرتر خواهند بود. استفاده از متانول، بنزول و و

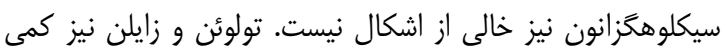

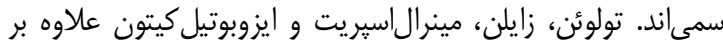
سمىبودن، اشكآور نيز هستند. البته استنشاق اين مواد وين و تماس بدن با حلالهاى غيرسمى در درازمدت روى اركانيزم بدن انسان و و

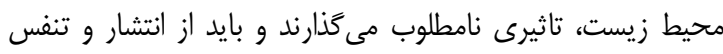

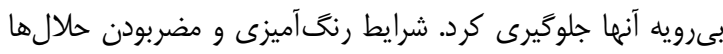

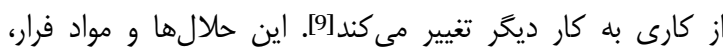

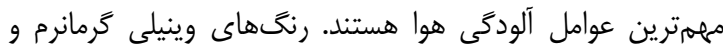

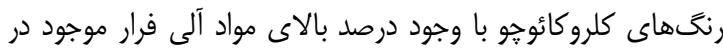

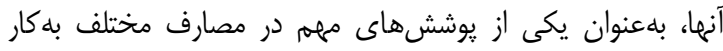

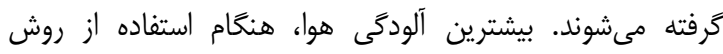

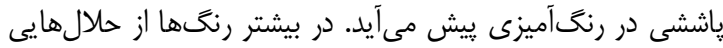

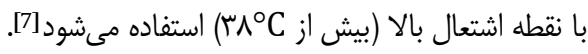
تاكنون مطالعاتى در زمينه اثرات سمى استنشاق كازهاى ناشى از

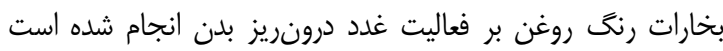
كه در اين ميان مىتوان به مطالعهاى در خصوص بررسى اثرات سرب بر محور هييوتالاموسى - هييوفيزى- كنادى اشاره كرد. آنها

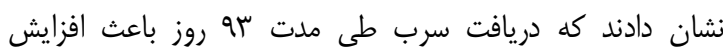
يراكسيداسيون ليبيدى هيبوفيز موشها در مقايسه با گروه كنترل

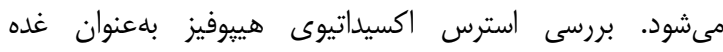

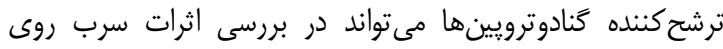
محور هييوتالاموسى - هييوفيزى- گ خنادى مفيد واقع شود. فعاليت FSH هم به مقدار اين دو هورمون و هم به تعداد گيرندهای مخدو مخصوص

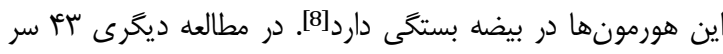

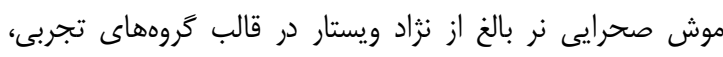

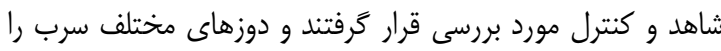


دور ... د در دقيقه قرار داده و سرم جدا شد و براى سنجش فاكتورها به كار رفت. بلمنظور آناليز دادهها، بسته نرمافزارى 20 SPSS مورد 20 مورد استفاده

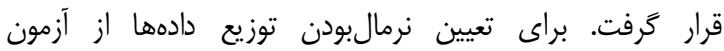

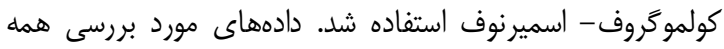

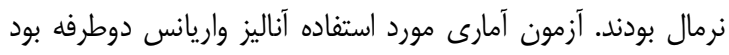

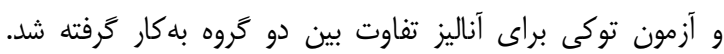
نتايج بهصورت ميانخين آمارى ارايه شد.

يافتهها ميانكَين سطح سرمى هورمون ترى يدوتيرونين (T⿰亻

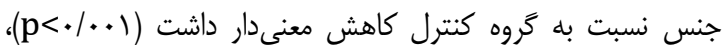

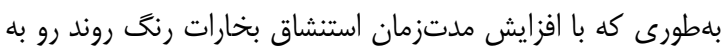

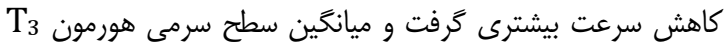

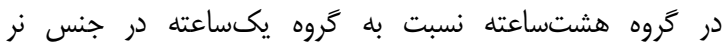

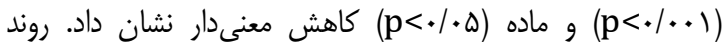

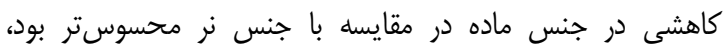
بلهورى كه بين دو جنس نر و ماده در كروه استنشاق يكساعناعته

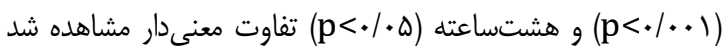

ميانگين سطح سرمى هورمون تيروكسين (T) (T) در كروههاى مورد

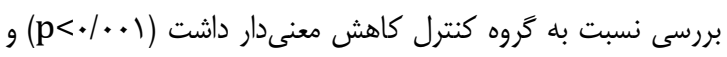

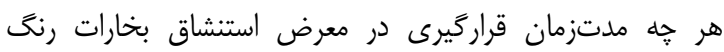

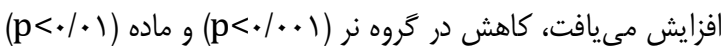

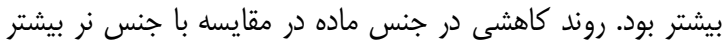

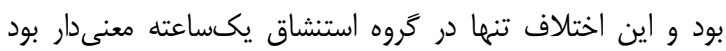

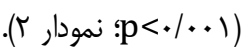

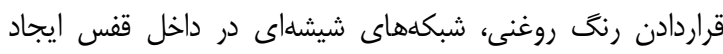

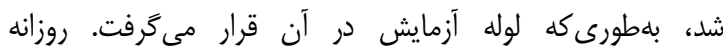

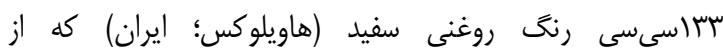
رنخفروشى خريدارى شده بود، داخل هر استوانه ريخته مى إندان.

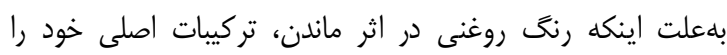

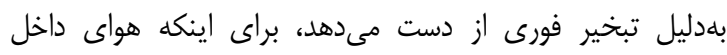

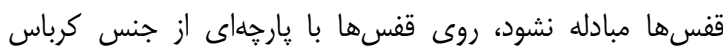

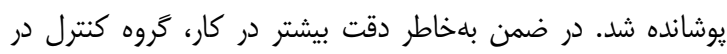

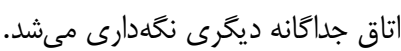

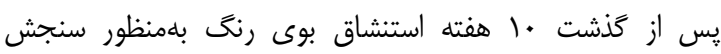

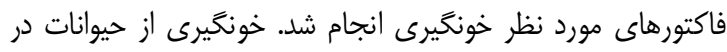

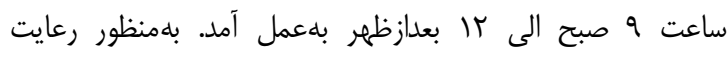

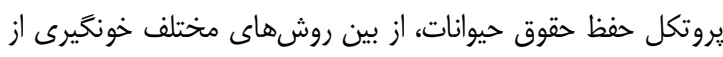

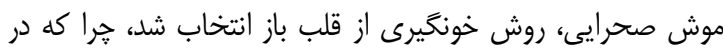

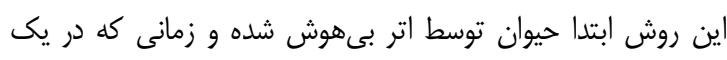

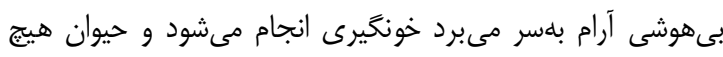

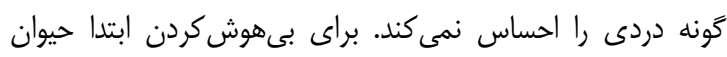

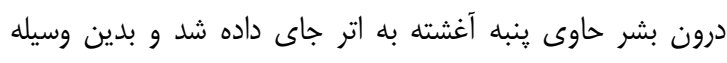

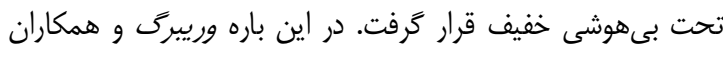

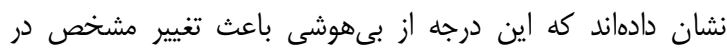

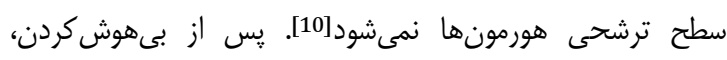

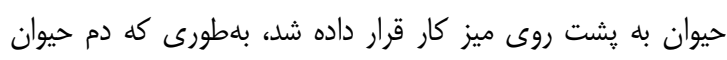

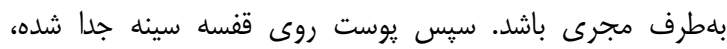

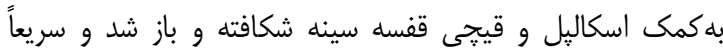

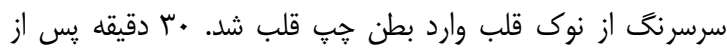

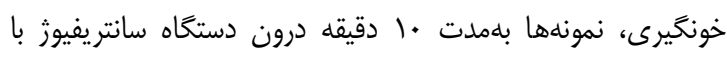

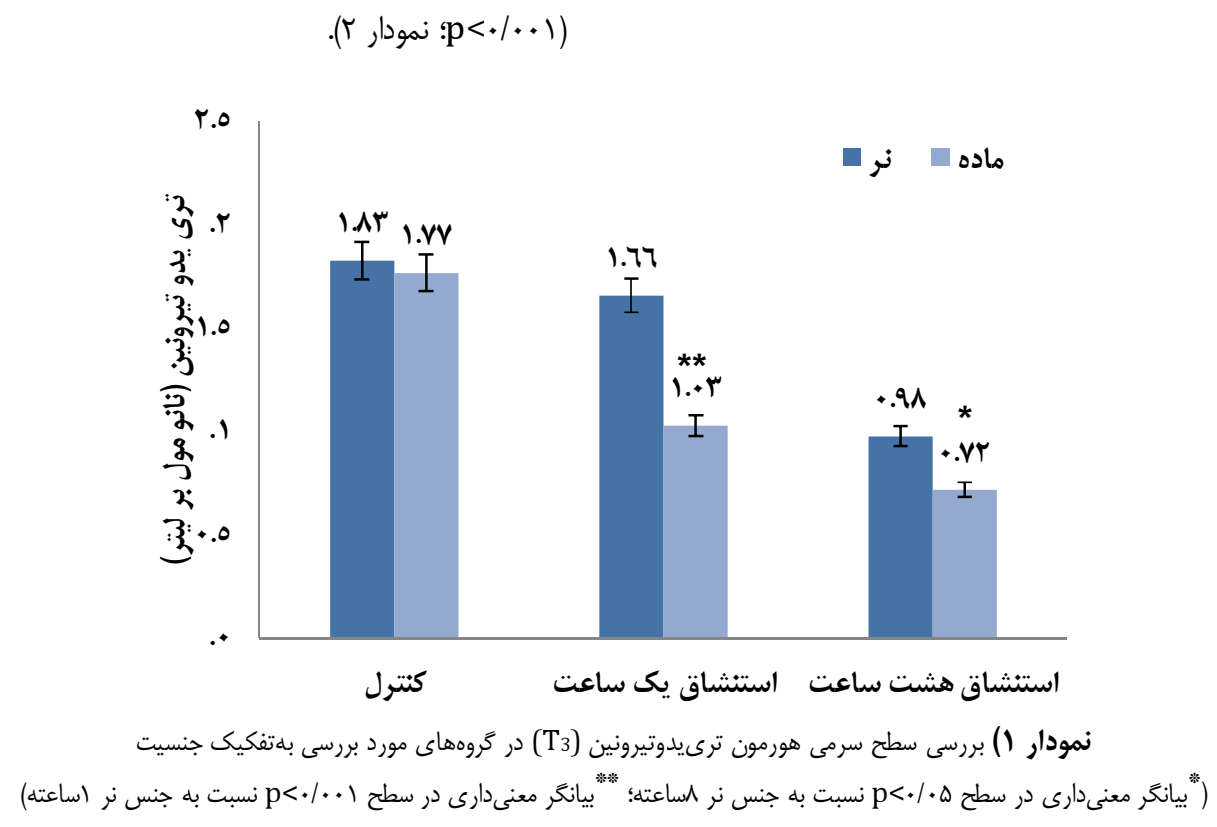

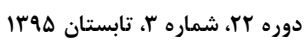

فصلنامه افق دانش 


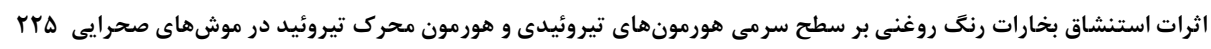

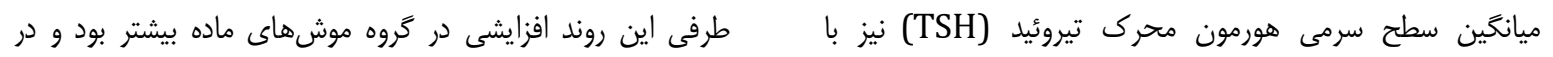

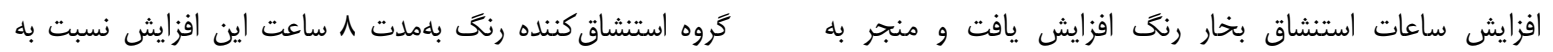

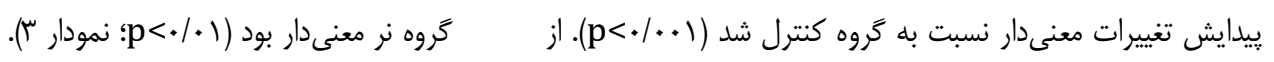
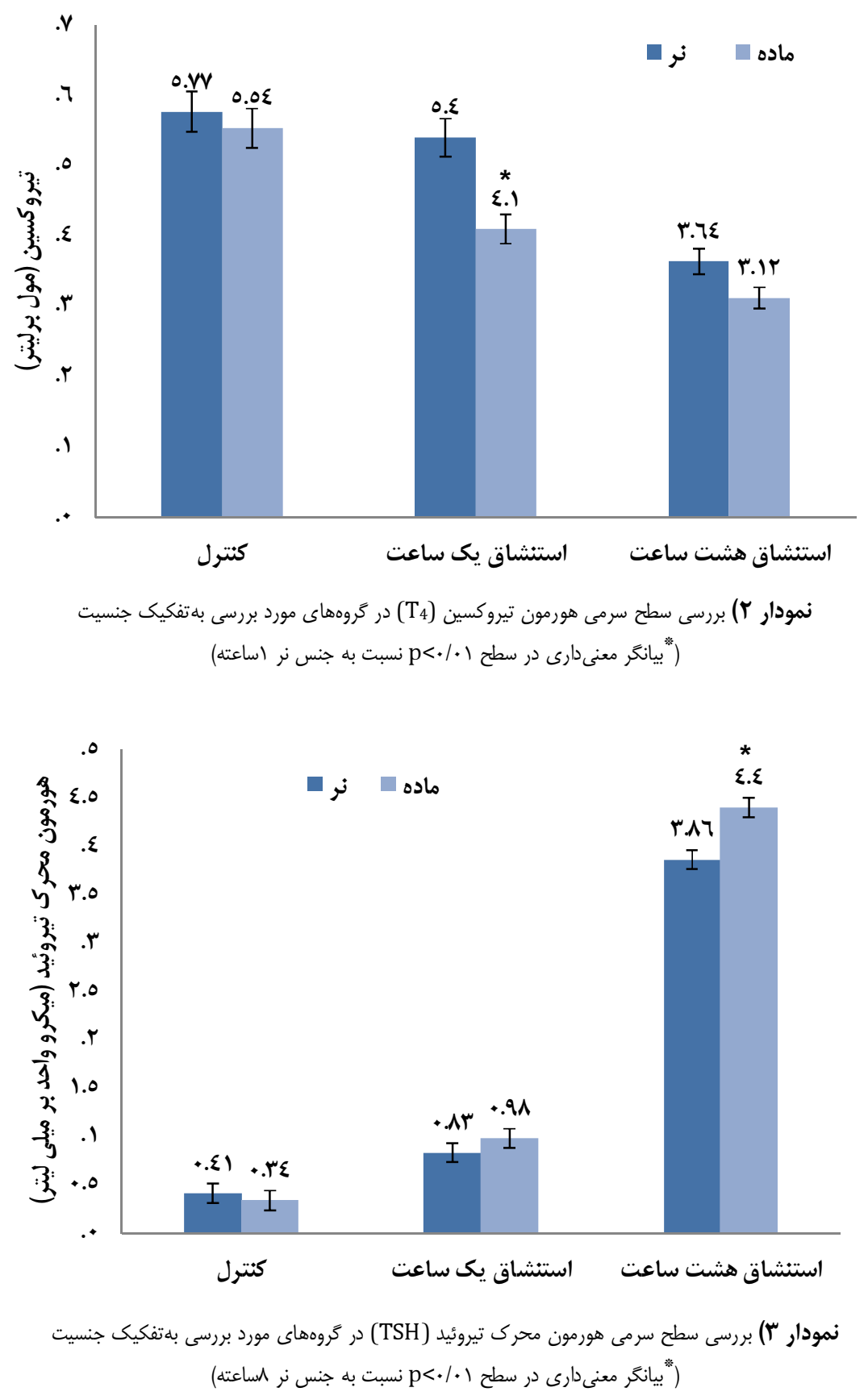

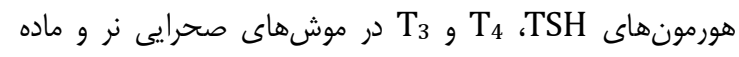

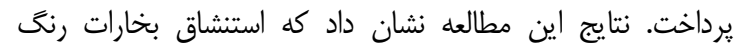

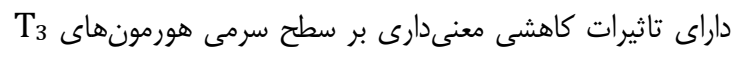

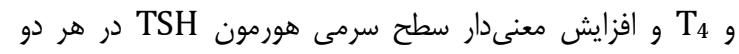

با توجه به احتمال آثار مضر سلامتى بهدليل استفاده از رنحكهاى

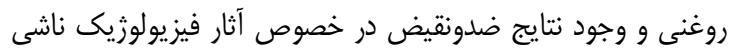

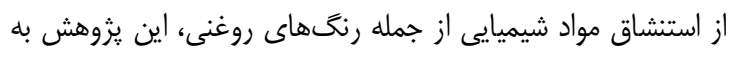

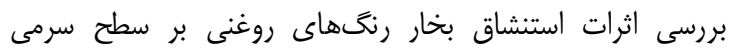


بلهوبه خود باعث افزايش ميزان هورمون TSH مىشود تا از اين

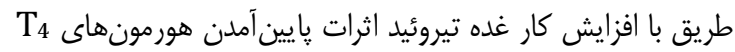

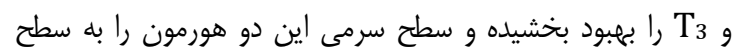

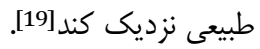

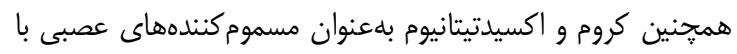
اثرات رفتارى و نوروشيميايى زيادى شناخته شدهاند. براساس

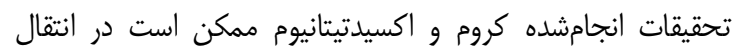

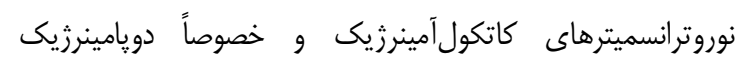

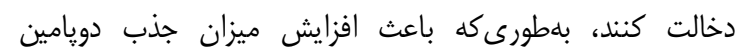

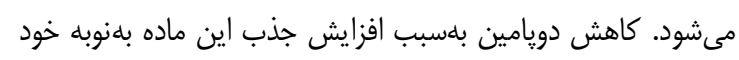

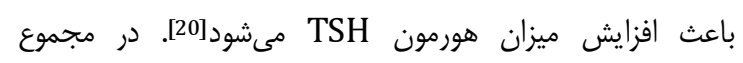

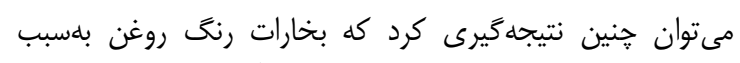

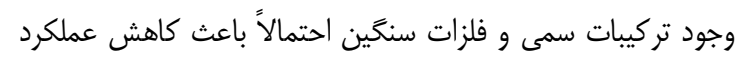

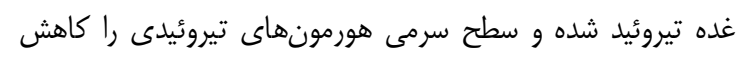

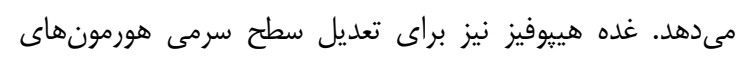

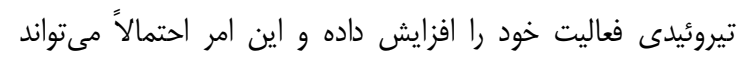

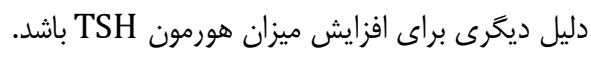

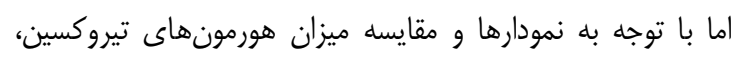

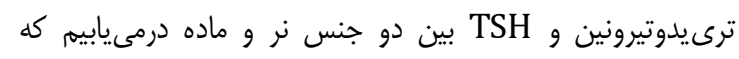

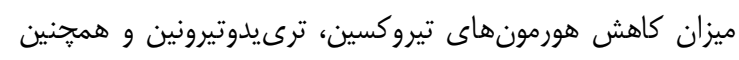

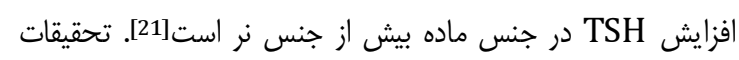

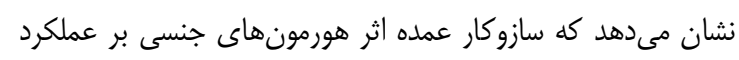

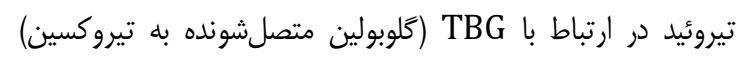

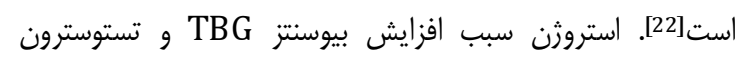
سبب كاهش سنتز TBG مىشود. بنابراين عملكرد استروزنها

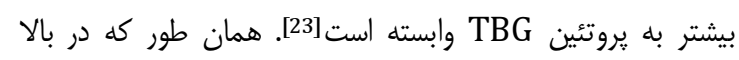

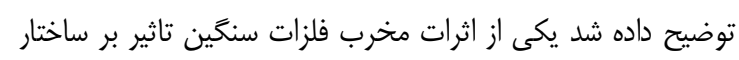

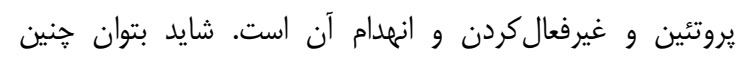

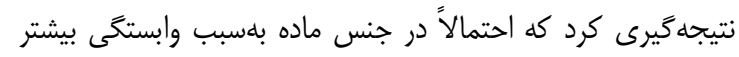

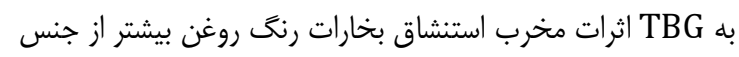

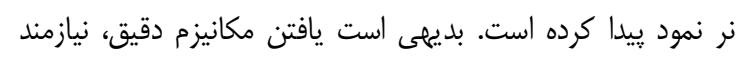
تحقيقات بيشترى است.

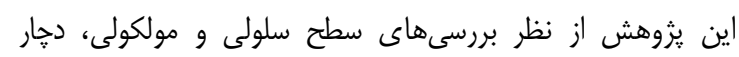

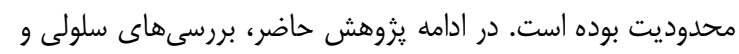

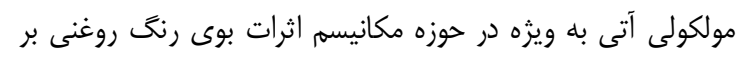

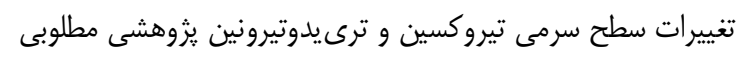

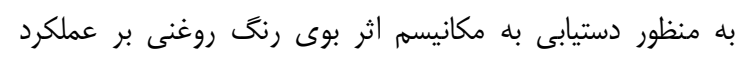
سطح سرمى هورمونهاى تيروئيدى است.

نتيجه كيرى استنشاق بخارات رنخ روغن باعث كاهش عملكرد غده تيروئيد شده و سطح سرمى هورمونهاى تيروئيدى
جنس نر و ماده است، بلهطورى كه با با افزايش زمان استنشاق بخار

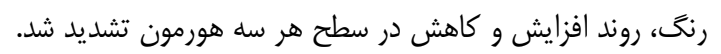

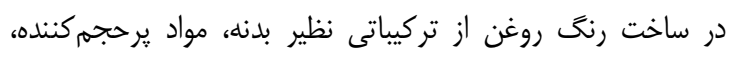

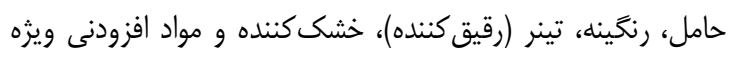

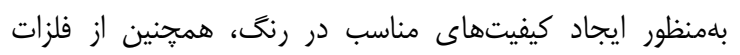
سنگينى همجيون كادميوم، سرب، كروم و اكسيدتيتانيانيوم استفاده

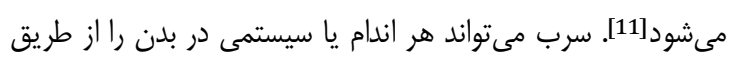

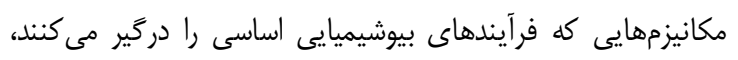

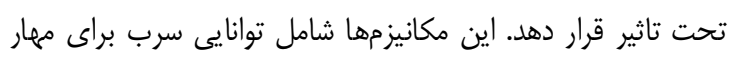

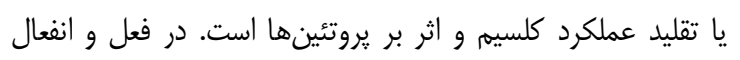

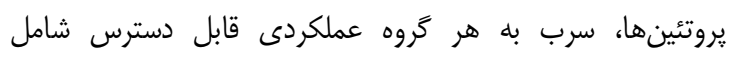

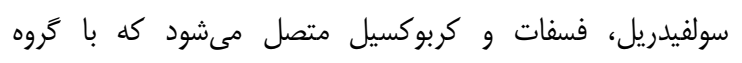

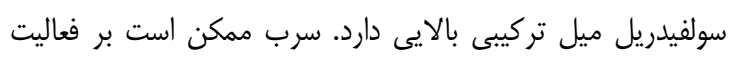

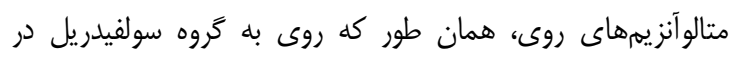

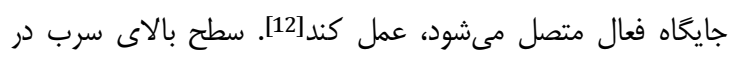

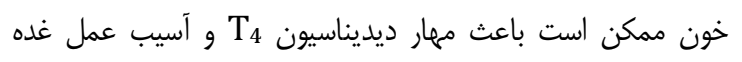

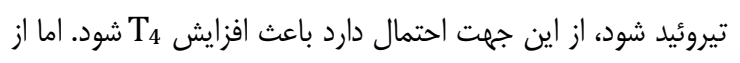

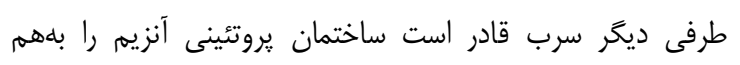

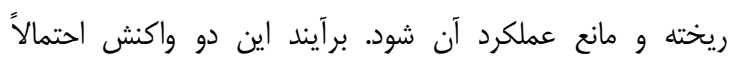

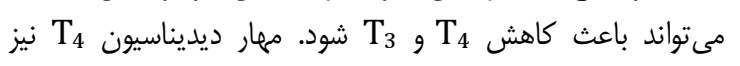

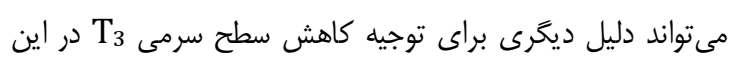
آزمايش باشد [13]. سرب فعاليت مونوآميناكسيداز و استيل كوليناستراز را افزايش

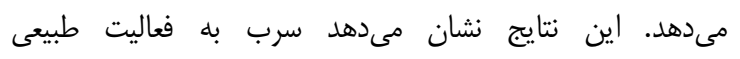

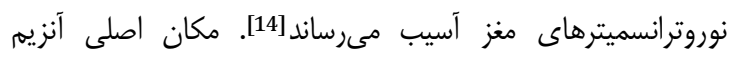

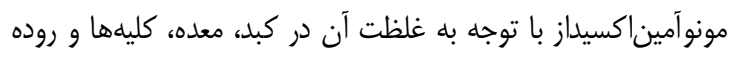

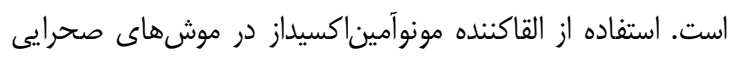

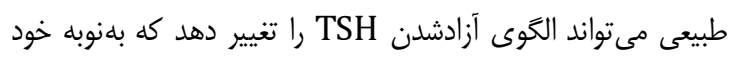

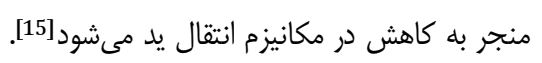

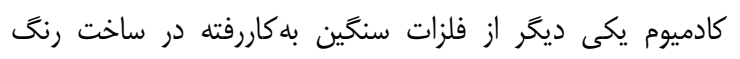

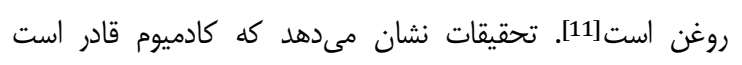

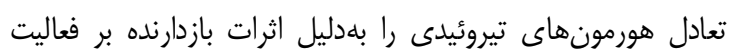

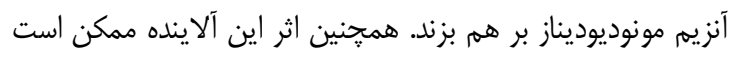

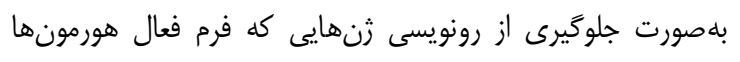

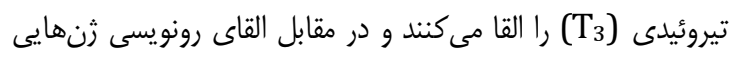

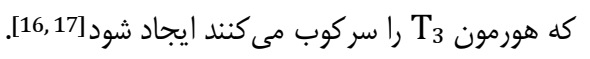

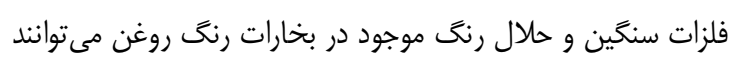

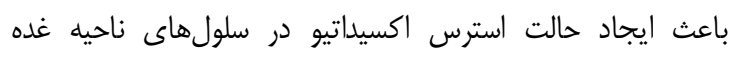

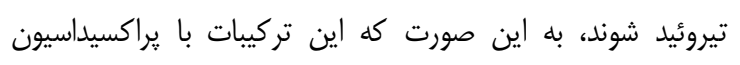

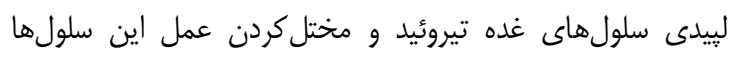

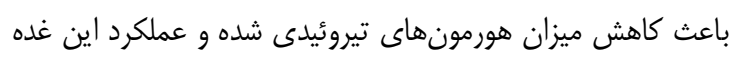

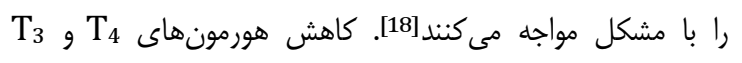
دوره rז، شماره r، تابستان هوسا فصل فامه افق دانش 
TrV اثرات استنشاق بخارات رنغ روغنى بر سطح سرمى هورمونهاى تيروئيدى و هورمون محرك تيروئيد در موشهاى صحرايى

Hormozgan Med J. 2007;11(2):115-20. [Persian]

10- Vreeburg JT, Samaun K, Verkade HJ, Verhoef P, Ooms

MP, Weber RF. Effects of corticosterone on the negative feedback action of testosterone, 5 alpha- dihydro testosterone and estradiol in the adult male rat. J Steroid Biochem. 1988;29(1):93-8.

11- Iyer RS, Scott JA. Power station fly ash-a review of value-added utilization outside of the construction industry. Resour Conserv Recycl. 2001;31(3):217-28.

12- Ford MD, Delaney KA, Ling LG, Erickson T. Toxicology. Philadelphia: W.B. Saunders; 2001. pp. 13344.

13- Lau YS, Camoratto AM, White LM, Moriarty CM. Effect of lead on TRH and GRF binding in rat anterior pituitary membranes. Toxicol. 1991;68(2):169-79.

14- Olney JW. New Insights and New Issues in Developmental Neurotoxicology. Neurotoxicology. 2002;23(6):659-68.

15- NourEddine D, Miloud S, Abdelkaader A. Effect of lead exposure on dopaminergic transmission in the rat brain. Toxicol. 2005;207(3):363-8.

16- Zhang F, Degitz SJ, Holcombe GW, Kosian PA, Tietge J, Veldhoen $\mathrm{N}$, et al. Evaluation of gene expression endpoints in the context a Xenopus laevis metamorphosis based bioassay to detect thyroid hormone disruptors. Aquat Toxicol. 2006;76(1):24-36.

17- Veldhoen N, Boggs A, Walzak K, Helbing CC. Exposure to tetrabromobisphenol-A alters TH-associated gene expression and tadpole metamorphosis in the Pacific tree frog Pseudacris regilla. Aquat Toxicol. 2006;78(3):292-302.

18- Kulikowska-Karpińska E, Moniuszko-Jakoniuk J. Lead and Zinc influence on antioxidant enzyme activity and melondialdhyde concentration in thyroid. Plish J Environ Stud. 2001;10(3):161-5.

19- Gustafson A, Hedner P, Schutz A, Skerfving S. Occuptional lead exposure and pituitary function. Int Arch Occup Environ Health. 1989;61(4):277-81.

20- Scott GR, Sloman KA. The effects of environmental pollutants on complex fish behaviour: Integrating behavioural and physiological indicators of toxicity. Aquat Toxicol. 2004;68(4):369-92.

21- Lazarus JH, Parkes AB, John R, N'Diaye M, PrysorJones SG. Endemic goitre in Senegal-thyroid function etiological factors and treatment with oral iodized oil. Acta Endocrinol (Copenh). 1992;126(2):149-54.

22- Pedraza PE, Obregon MJ, Escobar-Morreale HF, del Rey FE, de Escobar GM. Mechanisms of adaptation to iodine deficiency in rats: thyroid status is tissue specific, Its relevance for man. Endocrinol. 2006;147(5):2098108.

23- Knudsen N, Laurberg P, Perrild H, Bulow I, Ovesen L, Jorgensen T. Risk factors for goiter and thyroid nodules. Thyroid. 2002;12(10):879-88.

$$
\begin{aligned}
& \text { سطح سرمى هورمون TSH را افزايش مىدهد كه اين تاثير در } \\
& \text { جنس ماده بيشتر است. }
\end{aligned}
$$

تشكر و قدردانى: يزوهش حاضر با حمايتهاى معنوى و مادى

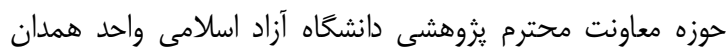

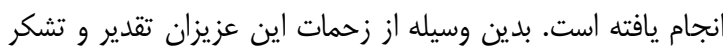
بلهمل مى آيد.

تاييديه اخلاقى: اين يزوهش با رعايت يروتكل حفظ حقوق

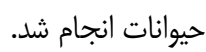

تعارض منافع: موردى از طرف نويسندگان بيان نشده است.

منابع مالى: اين يزوهش با حمايت مادى حوزه معاونت محترم يثزوشى دانشگًاه آزاد اسلامى واحد همدان انجام مام شده است.

\section{منابع}

1- Moeller LC, Broecker-Preuss M. Transcriptional regulation by nonclassical action of thyroid hormone. Thyroid Res. 2011;3(Suppl 4):S6.

2- Burel C, Boujard T, Kaushik SJ, Boeuf G, Mol KA, Van der Geyten S, et al. Effects of rapeseed mealglucosinolates on thyroid metabolism and feed utilization in rainbow trout. Gen Comp Endocrinol. 2001;124(3):343-58.

3- Kinne A, Schülein R, Krause G. Primary and secondary thyroid hormone transporters. Thyroid Res. 2011;4(Suppl 1):S7.

4- Eissenberg T, Shihadeh A. Waterpipe tobacco and cigarette smoking: Direct comparison of toxicant exposure. Am J Prev Med. 2009;37(6):518-23.

5- Costanza M, Musio S, Abou-Hamdan M, Binart N, Pedotti R. Prolactin is not required for the development of severe chronic experimental autoimmune encephalomyelitis. J Immunol. 2013;191(5):2082-8.

6- Vaziri ND, Ding Y. Effect of lead on nitric oxide synthase expression in coronary endothelial cells: Role of superoxide. Hypertens. 2001;37(2):223-6.

7- Arnold E, Thebault S, Baeza-Cruz G, Arredondo Zamarripa $\mathrm{D}$, Adán $\mathrm{N}$, et al. The hormone prolactin is a novel, endogenous trophic factor able to regulate reactive glia and to limit retinal degeneration. J Neurosci. 2014;34(5):1868-78.

8- Vigeh M, Smith DR, Hsu PC. How does lead induce male infertility?. Iran J Reprod Med. 2011;9(1):1-8.

9- Mokhtari M, Shariari M, Goshmardi N. Effect of lead on thyroid hormones and liver enzymes in adult male rats. 